\title{
Sterolibacterium denitrificans gen. nov., sp. nov., a novel cholesterol-oxidizing, denitrifying member of the $\beta$-Proteobacteria
}

\author{
Silvana Tarlera ${ }^{1}$ and Ewald B. M. Denner ${ }^{2}$ \\ ${ }^{1}$ Cátedra de Microbiología, Facultad de Química y Facultad de Ciencias, Universidad de la \\ República, C. C. 1157, Montevideo, Uruguay \\ ${ }^{2}$ Institut für Mikrobiologie und Genetik, Universität Wien, A-1030 Wien, Austria
}

Correspondence

Silvana Tarlera

starlera@fq.edu.uy

\begin{abstract}
A bacterial strain $\left(\mathrm{Chol}-1 \mathrm{~S}^{\top}\right.$ ) that is able to oxidize cholesterol to $\mathrm{CO}_{2}$ and reduce nitrate to dinitrogen was enriched and isolated from an upflow sludge bed (USB) anoxic reactor that treats sanitary landfill leachate from the city of Montevideo, Uruguay. Cells of strain Chol-1S $S^{\top}$ were Gram-negative, rod-shaped to slightly curved, measured 0.5-0.6 $\times 1.0-1.3 \mu \mathrm{m}$ and were motile by a single polar flagellum. Strain Chol- $1 \mathrm{~S}^{\top}$ grew optimally at $30-32^{\circ} \mathrm{C}$ and $\mathrm{pH} 7 \cdot 0$, with a doubling time of 44-46 $\mathrm{h}$ when cholesterol was used as the sole carbon and energy source. The metabolism of strain Chol-1 $\mathrm{S}^{\top}$ was strictly respiratory, with oxygen or nitrate as the terminal electron acceptor. The presence of ubiquinone Q-8 as the sole respiratory lipoquinone indicated that strain Chol-1S $\mathrm{S}^{\top}$ belonged to the $\beta$-subclass of the Proteobacteria. Phosphatidylethanolamine was the predominant polar lipid and the $\mathrm{G}+\mathrm{C}$ content of the DNA was $65.3 \mathrm{~mol} \%$. The fatty acid profile of strain Chol-1 $S^{\top}$, cultivated under denitrifying conditions by using a defined mineral medium supplemented with cholesterol, was characterized by the following major components: summed feature $4\left(\mathrm{C}_{16: 1} \omega 7 \mathrm{c}\right.$ and/or iso $\left.\mathrm{C}_{15: 0} 2-\mathrm{OH}\right), \mathrm{C}_{16: 0}, \mathrm{C}_{18: 1} \omega 7 \mathrm{c}$ and hydroxy acid $\mathrm{C}_{10: 0} 3-\mathrm{OH}$. Minor components included $\mathrm{C}_{10: 0}, \mathrm{C}_{11: 0}, \mathrm{C}_{12: 0}, \mathrm{C}_{14: 0}, \mathrm{C}_{15: 0}, \mathrm{C}_{19: 0}, \mathrm{C}_{19: 0}$ 10-methyl and hydroxylated acids $\mathrm{C}_{8: 0} 3-\mathrm{OH}$ and $\mathrm{C}_{16: 0} 3-\mathrm{OH}$. Analysis of the $16 \mathrm{~S}$ rDNA sequence showed that strain Chol-1S $\mathrm{S}^{\top}$ represents a separate lineage within the Thauera, Azoarcus, Zoogloea and Rhodocyclus assemblage of the $\beta$-Proteobacteria. Strain Chol-1S ${ }^{\top}$ had highest sequence similarity $(96.5 \%)$ with strain $72 \mathrm{Chol}$, a denitrifying $\beta$-Proteobacterium. On the basis of polyphasic evidence, strain Chol-1S $\mathrm{S}^{\top}\left(=\mathrm{DSM} 13999^{\top}=\right.$ ATCC BAA-354 $4^{\top}$ ) is proposed as the type strain of Sterolibacterium denitrificans gen. nov., sp. nov.
\end{abstract}

Cholesterol and related sterols are natural recalcitrants in anaerobic treatment of the highly pollutant effluent produced by the wool-scouring process (Gutiérrez et al., 1999). This can be attributed to the low number of functional groups (a carbon-carbon double bond and a hydroxyl group), its low solubility and the complexity of its spatial conformation. Aerobically, various genera of bacteria can degrade cholesterol completely to carbon dioxide by employing mono- and dioxygenases (Kieslich, 1985). However, less is known about the mechanisms that operate in the absence of oxygen. The best-studied anaerobic reaction so far is the reduction of cholesterol to coprostanol by intestinal fermentative bacteria (Freier et al., 1994).

Published online ahead of print on 6 December 2002 as DOI 10.1099/ ijs.0.02039-0.

Abbreviations: FAME, fatty acid methyl ester; USB, upflow sludge bed. The GenBank/EMBL/DDBJ accession number for the $16 \mathrm{~S}$ rRNA gene sequence of strain $\mathrm{Chol}-1 \mathrm{~S}^{\top}$ is AJ306683.
Due to their facultative metabolism, denitrifying bacteria are more versatile than other groups of bacteria and can serve as potential sources for novel biotransformations of natural substances. Previous work has demonstrated that denitrifying conditions can support the mineralization of cholesterol (Taylor et al., 1981). A denitrifying bacterial strain, 72Chol, which oxidizes cholesterol to carbon dioxide in the absence of molecular oxygen, was isolated from a leaf-covered ditch (Harder \& Probian, 1997).

A denitrifying post-treatment step of anaerobically pretreated wastewater can be envisaged to complement the removal of organic matter, in order to comply with environmental discharge standards. The purpose of this investigation was to determine whether organisms capable of anaerobic mineralization of cholesterol were present in different anaerobic man-made ecosystems that treat woolscouring effluent and sanitary landfill leachate. The latter ecosystem has high contents of readily degradable carbon but also of recalcitrant organic compounds, such as 
aromatics (Wang \& Barlaz, 1998). In the study presented here, we report the isolation and polyphasic characterization of a novel nitrate-reducing bacterium that oxidizes cholesterol to $\mathrm{CO}_{2}$.

\section{Source, enrichment and isolation}

Enrichment and cultivation were performed in a bicarbonate/ $\mathrm{CO}_{2}$-buffered, basal anaerobic mineral medium, modified from that of Tarlera et al. (1997) as follows $\left(1^{-1}\right): 1 \cdot 2 \mathrm{~g} \mathrm{~K}_{2} \mathrm{HPO}_{4}, 0 \cdot 4 \mathrm{~g} \mathrm{KH}_{2} \mathrm{PO}_{4}, 1 \cdot 0 \mathrm{~g} \mathrm{KNO}_{3}$ and $1 \mathrm{ml}$ $\left(25 \mathrm{~g} \mathrm{Na}_{2} \mathrm{~S}_{2} 9 \mathrm{H}_{2} \mathrm{O} \mathrm{l}^{-1}\right)$ solution. Prior to inoculation, $1 \mathrm{ml}$ vitamin solution (Touzel \& Albagnac, 1983), $20 \mathrm{ml}$ (11.6 g $\mathrm{MgCl}_{2} \cdot 6 \mathrm{H}_{2} \mathrm{O} \mathrm{l} \mathrm{l}^{-1}, 3.7 \mathrm{~g} \mathrm{CaCl} .2 \mathrm{H}_{2} \mathrm{O} \mathrm{l} \mathrm{l}^{-1}$ ) solution and substrates were added. Oxic liquid media did not contain nitrate or bicarbonate and were incubated with agitation. Soluble substrates were added from anaerobic filtersterilized stock solutions. Insoluble substrates were added either as a solid before autoclaving or as $1 \%(\mathrm{w} / \mathrm{v})$ solution in 2,2,4,4,6,8,8-heptamethylnonane as the inert carrier phase. All incubations were carried out at $30-32{ }^{\circ} \mathrm{C}$ and $\mathrm{pH} 7 \cdot 0$, except for tests to determine temperature and $\mathrm{pH}$ ranges for growth. For quantification studies, acetylene $(10 \%)$ was added to the culture headspace to block the last step of denitrification $\left(\mathrm{N}_{2} \mathrm{O} \rightarrow \mathrm{N}_{2}\right)$. Total $\mathrm{N}_{2} \mathrm{O}$ content was calculated from the headspace concentration as described by Christensen \& Tiedje (1988). Growth tests were considered to be positive for substrate utilization when an increase in optical density above that of control tubes with no added substrate was detected and confirmed by nitrate and nitrite quantification.

Denitrification in the presence of oxygen was tested by measuring the reduction of nitrate in anoxic and oxic conditions (incubated with agitation at 80 r.p.m.). Nitrate, nitrite and $\mathrm{N}_{2} \mathrm{O}$ were measured as described by Etchebehere et al. (2001). Volatile fatty acids, alcohols and sugars were analysed by HPLC as described by Menes \& Muxí (2002). For quantification of cholesterol, samples were extracted with ethyl acetate, evaporated under vacuum conditions, redissolved in methanol and analysed by UV (SPD-10AV; Shimadzu)-HPLC (Waters) at $210 \mathrm{~nm}$, by using a $\mathrm{C}_{18}$ column with a mobile phase of $60 / 40 \%(\mathrm{v} / \mathrm{v})$ acetonitrile/2propanol at a flow rate of $1.5 \mathrm{ml} \mathrm{min}{ }^{-1}$. Biomass was calculated from the total protein content of the cultures by using a protein per cell dry weight ratio of $50 \%$ and assuming the simplified cell formula $\mathrm{C}_{4} \mathrm{H}_{7} \mathrm{O}_{3}\left(M_{\mathrm{r}}=103\right)$. Protein determination was performed according to the Lowry method, by using BSA as the standard (Daniels et al., 1994).

Strain Chol- $1 S^{\mathrm{T}}$ was isolated from an upflow sludge bed (USB) denitrifying reactor that treats sanitary landfill leachate, after enrichment with cholesterol as the carbon source and nitrate as the electron acceptor (Barrandeguy \& Tarlera, 2001). Other enrichments, set up with inocula from anaerobic lagoons and reactors that treat wool-scouring effluent, failed to denitrify cholesterol.
Isolation of a pure culture was attempted from the cholesterol-degrading enrichment by: (a) streaking onto nutrient, brain-heart infusion (BHI) and R2A agar plates under air; (b) streaking onto anoxic plates of mineral medium with $10 \mathrm{mM}$ nitrate and an agar overlay of cholesterol; and (c) anoxic agar dilution and liquid dilution series of mineral medium with $1 \mathrm{mM}$ cholesterol and $10 \mathrm{mM}$ nitrate. Colonies that grew on solid media were transferred to liquid mineral medium with cholesterol as the sole carbon and energy source. None of the isolates was able to grow on cholesterol.

However, the isolation of a pure culture was successful after several successive anoxic liquid dilution series, which were subcultured as soon as nitrite production was detected in the highest dilutions. This strategy allowed enrichment of the cholesterol-degrading bacteria with respect to other bacteria. Finally, after consecutive series of dilutions that took place over 1 year, a pure culture that consisted only of straight or slightly curved short rods with rounded ends was obtained. The purity of the culture was tested by subculturing in mineral salt medium amended with volatile fatty acids, amino acids and ethanol (growth substrates commonly used by denitrifiers). In addition, the culture was transferred into complex media [oxic and anoxic TSB (trypticase soy broth), BHI and nutrient broth] and streaked onto different oxic and anoxic agar plates (R2A, TSA and nutrient agar). No growth was observed under the different conditions tested after more than 2 months of incubation. In a previous report, amplified rDNA restriction analysis (ARDRA), performed on the clones from the enrichment, revealed the presence of only two different restriction patterns (Barrandeguy \& Tarlera, 2001). The partial 16S rDNA sequence $(700 \mathrm{bp})$ that was representative of the dominant member of the enrichment, according to ARDRA, was identical to that determined later for strain Chol- $1 S^{\mathrm{T}}$. These results allow the conclusion that a pure culture was obtained.

\section{Morphological and physiological characteristics}

Cells of strain Chol- $1 S^{\mathrm{T}}$ were Gram-negative, straight to slightly curved rods $(0.5-0.6 \times 1 \cdot 0-1 \cdot 3 \mu \mathrm{m})$ that were motile by means of a single polar flagellum (Fig. 1a) and had lateral fimbria-like appendages (Fig. 1b).

Physiological characterization showed that strain Chol- $1 \mathrm{~S}^{\mathrm{T}}$ used only a limited number of substrates, including sterols and saturated long-chain fatty acids. Detailed physiological characteristics are listed in the formal species description below. Briefly, anaerobically grown cultures showed a lag phase before they started to grow with oxygen as the electron acceptor. Simultaneous reduction of oxygen and nitrate was not observed. The co-respiration of nitrate and oxygen under oxygen-saturated conditions is noted only for bacteria isolated from aerobic habitats, such as soil and activated sludge (Patureau et al., 1998; Rainey et al., 1999; Scholten et al., 1999). 

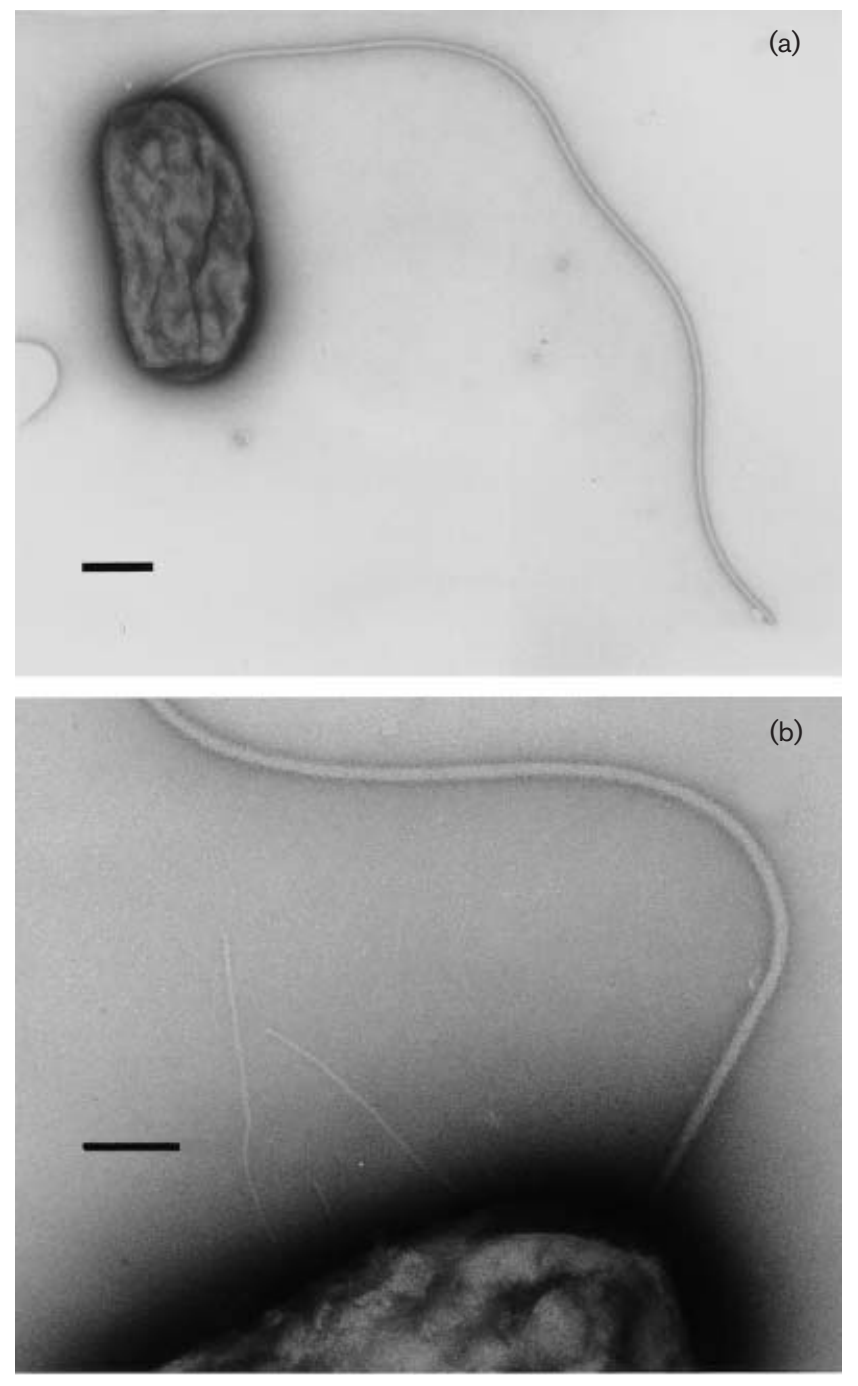

Fig. 1. Transmission electron micrographs of strain Chol-1 $\mathrm{S}^{\top}$, showing its morphology and flagellar position (a) and fimbrialike appendages (b). Bars, 0.3 $\mu \mathrm{m}$ (a); $50 \mathrm{~nm}$ (b).

\section{Oxidation of cholesterol}

Strain Chol- $1 \mathrm{~S}^{\mathrm{T}}$ was not able to grow with cholesterol as the electron donor, with sulphate, thiosulphate, fumarate or $\mathrm{Fe}(\mathrm{III})$ as electron acceptors or under fermentative conditions. Growth tests in an ammonium-free medium were likewise negative. After 10 weeks incubation, incomplete nitrate reduction (but no visible growth) was observed on acetate and propionate. Partial reduction $(2 \mathrm{mM})$ of nitrate to nitrite was observed on lithocholic acid. Noticeably, strain Chol- $1 S^{\mathrm{T}}$ has a narrow substrate-utilization profile that is specific for non-polar, hydrophobic compounds as carbon and energy sources.

To determine whether complete degradation of cholesterol was taking place, the oxidation of cholesterol and reduction of nitrate were quantified. The disappearance of $0.42 \mathrm{mM}$ cholesterol was accompanied by the consumption of
$9 \cdot 7 \mathrm{mM}$ nitrate and the synthesis of $120 \mathrm{mg}$ cell dry mass $1^{-1}$. Nitrite accumulated temporarily during growth, but was further consumed after near-depletion of nitrate (Fig. 2). More than $80 \%$ of nitrate reduced was recovered as dinitrogen oxide in experiments with an acetylene block, whereas only traces of dinitrogen oxide were detected in vials with no added acetylene. Also, as an increase in growth yield accompanied nitrate and nitrite reduction, a respiratory denitrification process could be ascertained. Timecourse analysis of growing cultures by HPLC showed no accumulation of short-chain fatty acids or alcohols in the culture broth of strain Chol-1 $S^{\mathrm{T}}$. Synthesis of biomass (120 $\mathrm{mg} \mathrm{l}^{-1}$; Fig. 2) can account for the consumption of $0.17 \mathrm{mM}$ cholesterol and $1.29 \mathrm{mM}$ nitrate based on the assimilation equation:

$$
\begin{aligned}
& 20 \mathrm{C}_{27} \mathrm{H}_{46} \mathrm{O}+149 \mathrm{NO}_{3}^{-}+149 \mathrm{H}^{+} \rightarrow \\
& 135 \mathrm{C}_{4} \mathrm{H}_{7} \mathrm{O}_{3}+74 \cdot 5 \mathrm{~N}_{2}+62 \mathrm{H}_{2} \mathrm{O}
\end{aligned}
$$

Initial and final cholesterol concentrations were 1 and $0.58 \mathrm{mM}$, respectively. Considering the cholesterol and nitrate consumed for cell synthesis, $0 \cdot 25 \mathrm{mM}$ cholesterol was dissimilated while $8.41 \mathrm{mM}$ nitrate was consumed and not recovered as nitrite. An electron recovery of $90 \%$ was calculated (the ratio of number of electrons produced by complete oxidation of the dissimilated amount of cholesterol to $\mathrm{CO}_{2}$ to number of electrons consumed by nitrate reduction to dinitrogen). The complete oxidation of $1 \mathrm{~mol}$ cholesterol yields $152 \mathrm{~mol}$ electrons; $5 \mathrm{~mol}$ electrons are considered to be accepted for $1 \mathrm{~mol}$ nitrate to be reduced

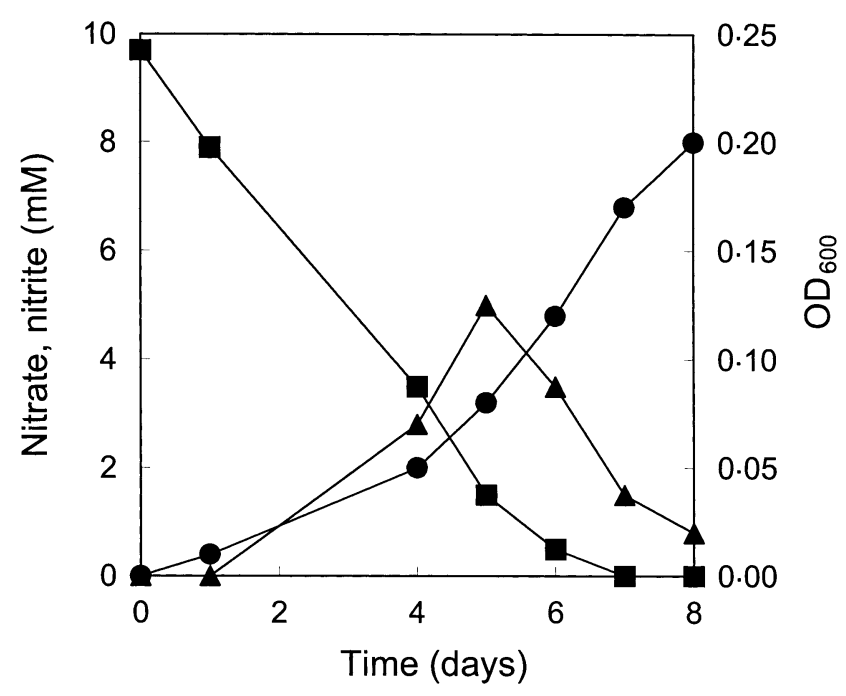

Fig. 2. Growth of strain Chol- $1 S^{\top}$ with cholesterol: $\mathrm{OD}_{600}(\bullet)$, nitrate consumption $(\boldsymbol{\square})$ and nitrite production $(\boldsymbol{\Delta})$. Data shown are representative of repeated experiments with similar results. Data are corrected for the amount of nitrate consumed in controls that lacked cholesterol. 
to dinitrogen. These findings are in good agreement with the theoretical stoichiometry for cholesterol mineralization according to the equation:

$$
\begin{aligned}
& \mathrm{C}_{27} \mathrm{H}_{46} \mathrm{O}+30 \cdot 4 \mathrm{NO}_{3}^{-}+30 \cdot 4 \mathrm{H}^{+} \rightarrow \\
& 27 \mathrm{CO}_{2}+15 \cdot 2 \mathrm{~N}_{2}+38 \cdot 2 \mathrm{H}_{2} \mathrm{O}
\end{aligned}
$$

\section{Chemotaxonomy}

Analysis of the respiratory lipoquinones was carried out by using HPLC at $30^{\circ} \mathrm{C}$ as described by Tindall (1990). The HPLC system was equipped with a model 510 pump, a model UK6 injector, a model 484 UV detector (all from Waters) and a reversed-phase column (Hypersil ODS RP 18, $250 \times 4 \cdot 6 \mathrm{~mm}, 5 \mu \mathrm{m}$ particles; Agilent Technologies). Analysis revealed a single peak that corresponded to ubiquinone-8 (Q-8). This quinone system is a characteristic feature of the $\beta$-Proteobacteria (Collins \& Jones, 1981; Yokota et al., 1992). Two-dimensional TLC of cellular lipids (Denner et al., 2001) indicated only the presence of phosphatidylethanolamine $(\mathrm{PE})$ in strain Chol-1S $\mathrm{S}^{\mathrm{T}}$. PE is one of the most widely occurring bacterial phospholipids (Wilkinson, 1988); solely PE was reported for Alcaligenes faecalis (Ghanekar \& Nair, 1974) and Azotobacter chroococcum (Reczek \& Burton, 1979). All other species of $\beta$-Proteobacteria that have been investigated so far have been shown to contain a more complex polar lipid pattern (Wilkinson, 1988; Cox \& Wilkinson, 1989; Yabuuchi et al., 1992, 1998; Blumel et al., 2001). Thus, the polar lipid pattern of strain Chol- $1 S^{\mathrm{T}}$ is a potentially distinctive trait of this species.

For fatty acid analysis, strain Chol- $1 S^{T}$ was grown on anaerobic mineral medium supplemented with $1 \mathrm{mM}$ cholesterol and $10 \mathrm{mM}$ nitrate, harvested by centrifugation, washed with $20 \mathrm{mM}$ phosphate buffer and freeze-dried. Fatty acid methyl esters (FAMEs) were extracted and prepared according to the standard protocol of the Microbial Identification system (MIDI; Microbial ID). FAME extract of strain Chol-1S $\mathrm{S}^{\mathrm{T}}$ was analysed by GLC as described by Kämpfer \& Kroppenstedt (1996). The fatty acid profile of strain Chol- $1 \mathrm{~S}^{\mathrm{T}}$ was characterized by $33 \cdot 8 \% \mathrm{C}_{16: 1} \omega 7 \mathrm{c}$ and/ or iso $\mathrm{C}_{15: 0} 2-\mathrm{OH}$ (summed feature 4 ), $21 \cdot 5 \% \mathrm{C}_{16: 0}, 14 \cdot 5 \%$ $\mathrm{C}_{18: 1} \omega 7 c$ and $14.0 \% \mathrm{C}_{10: 0} 3-\mathrm{OH}$. Other fatty acids that were present in significant amounts included $\mathrm{C}_{12: 0}(5 \cdot 3 \%)$, $\mathrm{C}_{19: 0}$ 10-methyl $(4 \cdot 0 \%)$ and $\mathrm{C}_{19: 0}(2 \cdot 3 \%)$. Fatty acids present in minor amounts included hydroxylated fatty acids $\mathrm{C}_{8: 0} 3-\mathrm{OH}(0 \cdot 2 \%)$ and $\mathrm{C}_{16: 0} 3-\mathrm{OH}(1 \cdot 0 \%)$ and saturated fatty acids $\mathrm{C}_{10: 0}(0 \cdot 9 \%), \mathrm{C}_{11: 0}(0 \cdot 2 \%), \mathrm{C}_{14: 0}(0.9 \%)$ and $\mathrm{C}_{15: 0}(0 \cdot 8 \%)$. Some unknown fatty acids were also present in minor amounts (data not shown). Similar fatty acid profiles have been described for the genera Thauera and Azoarcus (Song et al., 2001) and Zoogloea ramigera (Hiraishi et al., 1992); the presence of $\mathrm{C}_{8: 0} 3-\mathrm{OH}, \mathrm{C}_{16: 0} 3-\mathrm{OH}$ and $\mathrm{C}_{19: 0}$ 10-methyl was not reported (Hiraishi et al., 1992; Song et al., 2001), although a direct comparison of fatty acid profiles may be difficult because of the different cultivation conditions. However, fatty acid analysis clearly allows differentiation of strain Chol- $1 S^{\mathrm{T}}$ from these taxa.

\section{Phylogenetic position of strain Chol-1S}

Genomic DNA for 16S rDNA sequencing was extracted and purified by using the Wizard Genomic DNA purification kit (Promega) as described by the manufacturer. PCR amplification and sequencing were performed as described by Menes \& Muxí (2002). The primers used for sequencing were: 27F (positions 8-27: 5'-AGAGTTTGATCCTGGCTCAG-3'); ST1F (positions 606-632: 5'-GGCTCAACCTGGGAACT-3'); ST3F (positions 1273-1290: 5'-GAGCCAATCCCAGAAAG3'); ST4R (positions 1512-1496:5'-ACGGCTACCTTGTTACG3'); ST5R (positions 999-983:5-GCATGTCAAGGGTAGGT-3); and ST6R (positions 462-445: 5'-CCCAGTCCGTTTCTTCC$3^{\prime}$ ) (Escherichia coli numbering). Sequencing was carried out by the DNA Sequencing Core Laboratory at the University of Florida (USA). Phylogenetic analyses were performed with the PHYLIP 3.5c software package (Felsenstein, 1993) as described by Menes \& Muxí (2002).

A total of 1531 nt of the $16 \mathrm{~S}$ rRNA gene of strain Chol-1S ${ }^{\mathrm{T}}$ were determined. Phylogenetic analyses based on a dataset that comprised 1390 unambiguous nucleotides between positions 53 and 1459 (E. coli numbering) showed that the sequence of strain Chol-1S $S^{\mathrm{T}}$ is most similar to those of species of the $\beta$-subclass of the Proteobacteria (Fig. 3). Comparative evolutionary distance analysis showed that strain Chol- $1 S^{\mathrm{T}}$ represents a separate lineage of descent within the $\beta$-Proteobacteria. The nearest, albeit relatively distant, phylogenetic relatives were species of the genera Azoarcus, Thauera and Zoogloea. 16S rDNA sequence similarities ranged from $91 \%$ (with $Z$. ramigera ATCC $19544^{\mathrm{T}}$ ) to $93 \%$ (with Thauera linaloolentis DSM $12138^{\mathrm{T}}$ ). These similarity values are clearly below the usual criterion of $95 \%$ that is applied for genus delineation. The neighbourjoining tree inference clustered the genera Thauera, Azoarcus and Zoogloea at a significant level (86\%) in bootstrap analysis. Also, the branching of genera Propionivibrio, Rhodocyclus, Ferribacterium and Dechloromonas was supported by a high bootstrap value $(100 \%)$. Highest $16 \mathrm{~S}$ rRNA gene sequence similarity $(96 \cdot 5 \%)$ was found to the already mentioned denitrifying bacterial strain 72Chol (Harder \& Probian, 1997).

Comparative physiological investigations showed that strain $72 \mathrm{Chol}$ also uses only a limited number of substrates and degrades cholesterol and other sterols, but not short-chain fatty acids or sugars, under denitrifying conditions. In contrast to strain Chol- $1 S^{\mathrm{T}}$, strain $72 \mathrm{Chol}$ has been reported to be non-motile, has a maximum growth temperature of $32^{\circ} \mathrm{C}$, has a doubling time of $37 \mathrm{~h}$ on cholesterol and is unable to grow on palmitate (Harder \& Probian, 1997).

To summarize, by considering the polyphasic taxonomic data presented in this study, we could identify the novel cholesterol-oxidizing denitrifying bacterial isolate Chol- $1 \mathrm{~S}^{\mathrm{T}}$ as a hitherto unknown taxon of the $\beta$-Proteobacteria, for 


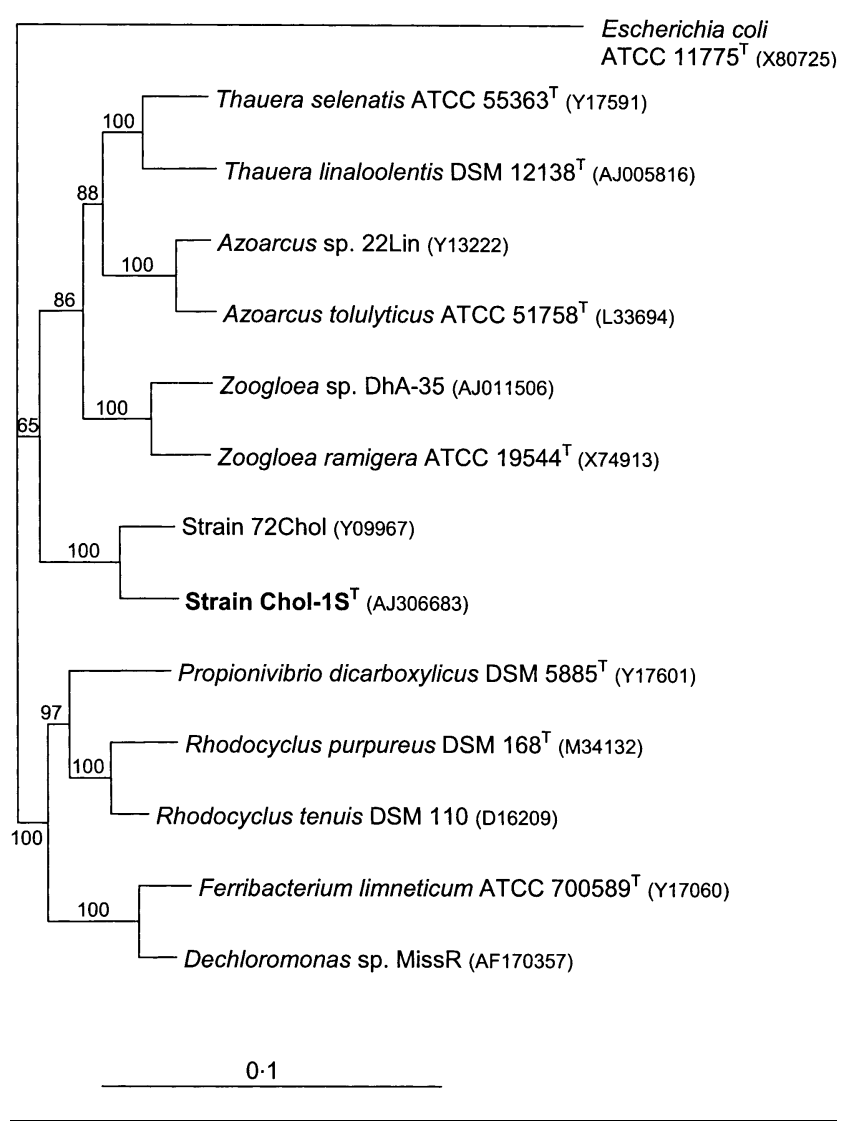

Fig. 3. Phylogenetic tree derived from the analysis of $16 \mathrm{~S}$ rRNA gene sequences of strain Chol-1S $S^{\top}$ and other related $\beta$ Proteobacteria. Numbers at nodes indicate levels of bootstrap support, based on data for 100 resamplings. E. coli was used as outgroup. Bar, 10 nucleotide substitutions per 100 nucleotide positions. which we propose the name Sterolibacterium denitrificans gen. nov., sp. nov. Key taxonomic characteristics that differentiate the genus Sterolibacterium from other related genera are listed in Table 1.

\section{Description of Sterolibacterium gen. nov.}

Sterolibacterium (Ste.ro.li.bac.te' ri.um. N.L. neut. n. sterolum sterol; Gr. dim. neut. n. bakterion small rod; N.L. neut. n. Sterolibacterium sterol-utilizing small rod).

Straight or slightly curved, small, rod-shaped, Gramnegative cells. Mesophilic. Strictly respiratory type of metabolism with oxygen or nitrate as terminal electron acceptor. Nitrate is reduced to dinitrogen. Oxidase- and catalase-positive. Chemo-organoheterotrophic. Does not grow on complex media. Cholesterol is completely oxidized to $\mathrm{CO}_{2}$; this reaction is coupled to nitrate reduction. Q-8 is the sole respiratory lipoquinone. Phosphatidylethanolamine is the predominant polar lipid. Major fatty acids are $\mathrm{C}_{16: 0}$, summed feature $4\left(\mathrm{C}_{16: 1} \omega 7 c\right.$ and/or iso $\left.\mathrm{C}_{15: 0} 2-\mathrm{OH}\right)$, $\mathrm{C}_{18: 1} \omega 7 c$ and $\mathrm{C}_{10: 0} 3-\mathrm{OH}$; minor amounts of $\mathrm{C}_{8: 0} 3-\mathrm{OH}$ and $\mathrm{C}_{16: 0}$ 3-OH are present. DNA $\mathrm{G}+\mathrm{C}$ content is $65.3 \mathrm{~mol} \%$ (HPLC). The type species of the genus is Sterolibacterium denitrificans.

\section{Description of Sterolibacterium denitrificans sp. nov.}

Sterolibacterium denitrificans (de.ni.tri'fi.cans. N.L. part. adj. denitrificans denitrifying).

Cells are $1 \cdot 0-1 \cdot 3 \times 0 \cdot 5-0.6 \mu \mathrm{m}$ in size and are motile by a single polar flagellum. Optimal $\mathrm{pH}$ and temperature for growth are $7 \cdot 0$ and $30-32{ }^{\circ} \mathrm{C}$, respectively. Temperature and pH ranges for growth are $15-35^{\circ} \mathrm{C}$ and $5 \cdot 8-8 \cdot 0$, respectively. Carbon sources used include cholesterol (5-cholesten-3 $\beta$-ol),

Table 1. Differential characteristics of Sterolibacterium gen. nov. and related taxa

Genera: 1, Sterolibacterium; 2, Thauera; 3, Azoarcus; 4, Zoogloea. Data for Thauera, Azoarcus and Zoogloea were compiled from Unz (1984), Hiraishi et al. (1997), Song et al. (1998, 2001) and Reinhold-Hurek \& Hurek (2000). +, Positive; -, negative.

\begin{tabular}{|lcccc|}
\hline Characteristic & $\mathbf{1}$ & $\mathbf{2}$ & $\mathbf{3}$ & $\mathbf{4}$ \\
\hline Growth on nutrient agar, R2A or BHI agar & - & + & + & + \\
Utilization as sole carbon source: & & & & + \\
$\quad$ Succinate & - & + & + & + \\
$\quad$ Acetate & - & + & + & + \\
$\quad$ Glutamate & - & + & + & Q-8, RQ-8 \\
Major quinone system & Q-8 & Q-8 & Q-8 & - \\
Diagnostic cellular fatty acids: & & & - & - \\
C $8: 0$ 3-OH & + & - & - & - \\
C $_{16: 0}$ 3-OH & + & - & - & $67-69$ \\
C $_{19: 0}$ 10-methyl & + & - & $64-68$ & \\
DNA G+C content (mol\%) & $65 \cdot 3$ & $64-69$ & & \\
\end{tabular}

${ }^{*} \mathrm{Q}-8$, ubiquinone-8; RQ-8, rhodoquinone-8. 
4-cholesten-3-one, $5 \alpha$-androstane-3,17-dione, 4 -androstene-3, 17-dione, $3 \beta$-hydroxy- $5 \alpha$-cholestane, palmitate $\left(\mathrm{C}_{16: 0}\right)$ and stearate $\left(\mathrm{C}_{18: 0}\right)$. Neither growth nor nitrate reduction was demonstrated after 6 months with glucose, fructose, xylose, ethanol, lactate, isobutyrate, succinate, malate, crotonate, citrate, laureate, oleate, caproate, heptanoate, cyclohexanol, cyclohexanone, glutamate, leucine, benzoate, phenol, cysteine, dimethylmalonate, desoxycholate or 1,4-androstadiene3,17-dione. Doubling time for growth on cholesterol and nitrate is $44-46 \mathrm{~h}$.

The type strain is Chol-1S ${ }^{\mathrm{T}}\left(=\right.$ DSM $13999^{\mathrm{T}}=$ ATCC BAA$\left.354^{\mathrm{T}}\right)$. Isolated from a USB denitrifying reactor that treats sanitary landfill leachate in Montevideo, Uruguay.

\section{Acknowledgements}

We are grateful to Professor Dr Peter Kämpfer, Institut für Angewandte Mikrobiologie, Justus-Liebig-Universität Gießen, Germany, for performing the fatty acid analysis and helpful suggestions. Professor Hans Trüper (University of Bonn, Germany) is acknowledged for advice on Latin usage. S. T. also wishes to thank Lucía Muxí for her encouragement and valuable advice. This study was partly supported by PEDECIBA, a Program for the Development of Basic Sciences in Uruguay and by Universidad de la República (CSIC). Transmission electron microscopy and analysis of DNA G + C content was carried out by the Identification Service of the Deutsche Sammlung von Mikroorganismen und Zellkulturen - DSMZ, Braunschweig, Germany.

\section{References}

Barrandeguy, E. \& Tarlera, S. (2001). Anaerobic oxidation of cholesterol by a denitrifying enrichment. Water Sci Technol 44, 145-150.

Blümel, S., Mark, B., Busse, H.-J., Kämpfer, P. \& Stolz, A. (2001). Pigmentiphaga kullae gen. nov., sp. nov., a novel member of the family Alcaligenaceae with the ability to decolorize azo dyes aerobically. Int J Syst Evol Microbiol 51, 1867-1871.

Christensen, S. \& Tiedje, J. M. (1988). Sub-parts-per-billion nitrate method: use of an $\mathrm{N}_{2} \mathrm{O}$-producing denitrifier to convert $\mathrm{NO}_{3}^{-}$or ${ }^{15} \mathrm{NO}_{3}^{-}$to $\mathrm{N}_{2} \mathrm{O}$. Appl Environ Microbiol 54, 1409-1413.

Collins, M. D. \& Jones, D. (1981). Distribution of isoprenoid quinone structural types in bacteria and their taxonomic implication. Microbiol Rev 45, 316-354.

Cox, A. D. \& Wilkinson, S. G. (1989). Polar lipids and fatty acids of Pseudomonas cepacia. Biochim Biophys Acta 1001, 60-67.

Daniels, L., Hanson, R. S. \& Phillips, J. A. (1994). Chemical analysis. In Methods for General and Molecular Bacteriology, pp. 514-554. Edited by P. Gerhardt, R. G. E. Murray, W. A. Wood \& N. R. Krieg. Washington, DC: American Society for Microbiology.

Denner, E. B. M., Paukner, S., Kämpfer, P., Moore, E. R. B., Abraham, W.-R., Busse, H.-J., Wanner, G. \& Lubitz, W. (2001). Sphingomonas pituitosa sp. nov., an exopolysaccharide-producing bacterium that secretes an unusual type of sphingan. Int J Syst Evol Microbiol 51, 827-841.

Etchebehere, C., Errazquin, I., Barrandeguy, E., Dabert, P., Moletta, R., Muxí. \&, L. (2001). Evaluation of the denitrifying microbiota of anoxic reactors. FEMS Microbiol Ecol 35, 259-265.

Felsenstein, J. (1993). PHYLIP (phylogeny inference package), version 3.5c. Department of Genetics, University of Washington, Seattle, USA.
Freier, T. A., Beitz, D. C., Li, L. \& Hartman, P. A. (1994). Characterization of Eubacterium coprostanoligenes sp. nov., a cholesterolreducing anaerobe. Int J Syst Bacteriol 44, 137-142.

Ghanekar, A. S. \& Nair, P. M. (1974). Lipids of Alcaligenes faecalis. Indian J Biochem Biophys 11, 233-236.

Gutiérrez, S., Hernández, A. \& Viñas, M. (1999). Mechanisms of degradation of wool wax in the anaerobic treatment of woolscouring wastewater. Water Sci Technol 40, 17-23.

Harder, J. \& Probian, C. (1997). Anaerobic mineralization of cholesterol by a novel type of denitrifying bacterium. Arch Microbiol 167, 269-274.

Hiraishi, A., Shin, Y. K., Sugiyama, J. \& Komagata, A. (1992). Isoprenoid quinones and fatty acids of Zoogloea. Antonie van Leeuwenhoek 61, 231-236.

Hiraishi, A., Shin, Y. K. \& Sugiyama, J. (1997). Proposal to reclassify Zoogloea ramigera IAM 12670 (P. R. Dugan 115) as Duganella zoogloeoides gen. nov., sp. nov. Int J Syst Bacteriol 47, $1249-1252$.

Kämpfer, P. \& Kroppenstedt, R. M. (1996). Numerical analysis of fatty acid patterns of coryneform bacteria and related taxa. Can J Microbiol 42, 989-1005.

Kieslich, K. (1985). Microbial side-chain degradation of sterols. J Basic Microbiol 25, 461-474.

Menes, R. J. \& Muxí, L. (2002). Anaerobaculum mobile sp. nov., a novel anaerobic, moderately thermophilic, peptide-fermenting bacterium that uses crotonate as an electron acceptor, and emended description of the genus Anaerobaculum. Int J Syst Evol Microbiol 52, 157-164.

Patureau, D., Godon, J.-J., Dabert, P., Bouchez, T., Bernet, N., Delgenes, J. P. \& Moletta, R. (1998). Microvirgula aerodenitrificans gen. nov., sp. nov., a new Gram-negative bacterium exhibiting corespiration of oxygen and nitrogen oxides up to oxygen-saturated conditions. Int J Syst Bacteriol 48, 775-782.

Rainey, F. A., Kelly, D. P., Stackebrandt, E., Burghardt, J., Hiraishi, A., Katayama, Y. \& Wood, A. P. (1999). A re-evaluation of the taxonomy of Paracoccus denitrificans and a proposal for the combination Paracoccus pantotrophus comb. nov. Int J Syst Bacteriol 49, 645-651.

Reczek, E. B. \& Burton, D. N. (1979). Effects of oxygen tension on the lipid composition of Azotobacter chroococcum. Can J Microbiol 25, 1239-44.

Reinhold-Hurek, B. \& Hurek, T. (2000). Reassessment of the taxonomic structure of the diazotrophic genus Azoarcus sensu lato and description of three new genera and new species, Azovibrio restrictus gen. nov., sp. nov., Azospira oryzae gen. nov., sp. nov. and Azonexus fungiphilus gen. nov., sp. nov. Int J Syst Evol Microbiol 50, 649-659.

Scholten, E., Lukow, T., Auling, G., Kroppenstedt, R. M., Rainey, F. A. \& Diekmann, H. (1999). Thauera mechernichensis sp. nov., an aerobic denitrifier from a leachate treatment plant. Int J Syst Bacteriol 49, 1045-1051.

Song, B., Young, L. Y. \& Palleroni, N. J. (1998). Identification of denitrifier strain $\mathrm{T} 1$ as Thauera aromatica and proposal for emendation of the genus Thauera definition. Int J Syst Bacteriol 48, 889-894.

Song, B., Palleroni, N. J., Kerkhof, L. J. \& Häggblom, M. M. (2001). Characterization of halobenzoate-degrading, denitrifying Azoarcus and Thauera isolates and description of Thauera chlorobenzoica sp. nov. Int J Syst Evol Microbiol 51, 589-602.

Tarlera, S., Muxí, L., Soubes, M. \& Stams, A. J. M. (1997). Caloramator proteoclasticus sp. nov., a new moderately thermophilic anaerobic proteolytic bacterium. Int J Syst Bacteriol 47, 651-656. 
Taylor, C. D., Smith, S. O. \& Gagosian, R. B. (1981). Use of microbial enrichments for the study of the anaerobic degradation of cholesterol. Geochim Cosmochim Acta 45, 2161-2168.

Tindall, B. J. (1990). Lipid composition of Halobacterium lacusprofundi. FEMS Microbiol Lett 66, 199-202.

Touzel, J. P. \& Albagnac, G. (1983). Isolation and characterization of Methanococcus mazei strain MC3. FEMS Microbiol Lett 16, 241-245.

Unz, R. F. (1984). Genus IV. Zoogloea Itzigsohn 1868, 30. In Bergey's Manual of Systematic Bacteriology, vol. 1, pp. 214-219. Edited by N. R. Krieg \& J. G. Holt. Baltimore: Williams \& Wilkins.

Wang, Y.-S. \& Barlaz, M. A. (1998). Anaerobic biodegradability of alkylbenzenes and phenol by landfill derived microorganisms. FEMS Microbiol Ecol 25, 405-418.

Wilkinson, S. G. (1988). Gram-negative bacteria. In Microbial Lipids, vol. 1, pp. 299-487. Edited by S. G. Wilkinson \& C. Ratledge. New York: Academic Press.
Yabuuchi, E., Kosako, Y., Oyaizu, H., Hotta, H., Yano, I., Hashimoto, Y., Ezaki, T. \& Arakawa, M. (1992). Proposal of Burkholderia gen. nov. and transfer of seven species of the genus Pseudomonas homology group II to the new genus, with the type species Burkholderia cepacia (Palleroni and Holmes 1981) comb. nov. Microbiol Immunol 36, 1251-1275.

Yabuuchi, E., Kawamura, Y., Kosako, Y. \& Ezaki, T. (1998). Emendation of genus Achromobacter and Achromobacter xylosoxidans (Yabuuchi and Yano) and proposal of Achromobacter ruhlandii (Packer and Vishniac) comb. nov., Achromobacter piechaudii (Kiredjian et al.) comb. nov., and Achromobacter xylosoxidans subsp. denitrificans (Ruger and Tan) comb. nov. Microbiol Immunol 42, 429-438.

Yokota, A., Akagawa-Matsushita, M., Hiraishi, A., Katayama, Y., Urakami, T. \& Yamasato, K. (1992). Distribution of quinone systems in microorganisms: Gram-negative eubacteria. Bull Jpn Fed Cult Coll 8, 136-171. 